\title{
New Bulk Glassy Ni-Based Alloys with High Strength of 3000 MPa
}

\author{
Tao Zhang and Akihisa Inoue \\ Institute for Materials Research, Tohoku University, Sendai 980-8577, Japan
}

New Ni-based bulk glassy alloys with high strength and good ductility were synthesized for the first time in $\mathrm{Ni}-\mathrm{Nb}-\mathrm{Ti}-\mathrm{Zr}$ base system by the mold-clamp or copper mold casting method. The bulk glassy $\mathrm{Ni}_{53} \mathrm{Nb}_{20} \mathrm{Ti}_{10} \mathrm{Zr}_{8} \mathrm{Co}_{6} \mathrm{Cu}_{3}$ alloy has a rod shape with diameters up to $3 \mathrm{~mm}$ or a sheet shape with thickness up to $1 \mathrm{~mm}$. The glass transition temperature $\left(T_{\mathrm{g}}\right)$ and the supercooled liquid region defined by the difference between $T_{\mathrm{g}}$ and crystallization temperature $\left(T_{\mathrm{x}}\right), \Delta T_{\mathrm{x}}\left(=T_{\mathrm{x}}-T_{\mathrm{g}}\right)$ are 846 and $51 \mathrm{~K}$, respectively, and no distinct change in $T_{\mathrm{g}}, T_{\mathrm{X}}$ and $\Delta T_{\mathrm{x}}$ with sample diameter is seen. The Ni-based alloy is located in the vicinity of eutectic composition and has a high reduced glass transition temperature $\left(T_{\mathrm{g}} / T_{\mathrm{m}}\right)$ of 0.67 . The Ni-based bulk glassy alloy also exhibits good mechanical properties, i.e., tensile fracture strength of $2700 \mathrm{MPa}$, tensile fracture elongation of $2.1 \%$, compressive fracture strength of $3010 \mathrm{MPa}$ and compressive fracture elongation of $2.4 \%$. It is noticed that the tensile fracture strength is the highest among all bulk glassy alloys developed up to date. The success of synthesizing the new Ni-based bulk glassy alloy with good mechanical properties is promising for future uses as a new type of high strength material.

(Received November 21, 2001; Accepted February 25, 2002)

Keywords: nickel base alloy, bulk glassy alloy, glass transition, supercooled liquid region, reduced glass transition temperature, high strength, large elongation

\section{Introduction}

Since the success of forming bulk glassy alloys with a large supercooled liquid region before crystallization and good mechanical properties in lanthanide ( $\mathrm{Ln})_{-}{ }^{1)}$ and $\mathrm{Mg}_{-}{ }^{2}$ ) based systems by a copper mold casting method in late 1980's, great attention has been devoted to synthesis and properties of a new bulk glassy alloy. It is well known that a number of bulk glassy alloys were subsequently developed in the order of $\mathrm{Zr}-,{ }^{3,4)} \mathrm{Ti}-,{ }^{5)} \mathrm{Hf}-,{ }^{6)} \mathrm{Fe}-{ }^{7)} \mathrm{Pd}-\mathrm{Cu}-,{ }^{8)} \mathrm{Pd}-\mathrm{Fe}-$, $\left.{ }^{9}\right)$ $\mathrm{Co}_{-}{ }^{10)} \mathrm{Ni}^{11)}$ and $\mathrm{Cu}^{-}{ }^{12)}$ based alloy systems and the maximum sample thickness reaches as large as about $10 \mathrm{~mm}^{13)}$ for the Ln-based alloys, $12 \mathrm{~mm}^{14)}$ for the Mg-based alloys, 15 to $30 \mathrm{~mm}^{4,15)}$ for the Zr-based alloys, $5 \mathrm{~mm}^{16)}$ for the Fe-based alloys, $75 \mathrm{~mm}^{17)}$ for the $\mathrm{Pd}-\mathrm{Cu}$-based alloys, $2 \mathrm{~mm}$ for the $\mathrm{Co}^{18)}$ and $\mathrm{Ni}^{19}{ }^{19)}$ based alloys and $5 \mathrm{~mm}^{20}$ ) for the $\mathrm{Cu}$-based alloys. Among these bulk glassy alloys, it has been reported that high tensile strength combined with good ductility is obtained for the Ln-, Zr-, Hf-, $\mathrm{Pd}-\mathrm{Cu}$ - and $\mathrm{Cu}$-based alloys and good soft magnetic properties are obtained for the $\mathrm{Fe}$ - and Co-based alloys. ${ }^{21-25)}$ When we pay attention to high-strength glassy alloys with good ductility, the tensile strength level has been reported to be $1200 \mathrm{MPa}$ for the Ln-based alloys, ${ }^{24)} 1500$ to $1700 \mathrm{MPa}$ for the $\mathrm{Zr}$-, Hf- and $\mathrm{Pd}-\mathrm{Cu}$-based alloys ${ }^{24)}$ and 2000 to $2500 \mathrm{MPa}^{12,20)}$ for the $\mathrm{Cu}$-based alloys. Although much higher mechanical strength is expected to be obtained for the ferrous group glassy alloys in $\mathrm{Fe}-$, $\mathrm{Co}-$ and Ni-based alloy systems, high tensile strength exceeding $2500 \mathrm{MPa}$ has not been achieved because of their poor ductility leading to fracture within elastic limit. The expectation of achieving high mechanical strength in the ferrous alloy group by improving ductility is supported from some experimental data that high compressive fracture strength of about $2500 \mathrm{MPa}$ has been obtained for Ni-based metal-metalloid type bulk glassy alloys. ${ }^{19)}$ Based on the recent data on the new alloy compositions of the $\mathrm{Cu}$-based bulk glassy alloys with high tensile strength of 2000 to $2500 \mathrm{MPa},{ }^{12,20,25)}$ we have subsequently performed a study to synthesize a new bulk glassy alloy with much higher tensile strength in the ferrous alloy groups by finding a new alloy composition at which a good ductility without fracture in the elastic limit is obtained. We have succeeded for the first time in synthesizing new bulk glassy Ni-based alloys with high tensile strength of $2700 \mathrm{MPa}$ and high compressive fracture strength of $3010 \mathrm{MPa}$. This paper intends to present the compositions, thermal stability and mechanical properties of the high-strength Ni-based bulk glassy alloys.

\section{Experimental Procedure}

Multicomponent alloy ingots with composition of $\mathrm{Ni}_{53} \mathrm{Nb}_{20} \mathrm{Ti}_{10} \mathrm{Zr}_{8} \mathrm{Co}_{6} \mathrm{Cu}_{3}$ were prepared by arc melting the mixtures of pure metals in an argon atmosphere. The composition represent nominal atomic percentages. Bulk glassy alloys were prepared in a cylindrical rod shape with diameters up to $5 \mathrm{~mm}$ by the copper mold casting method and in a sheet shape with thickness up to $3 \mathrm{~mm}$ by the mold-clamp casting method. ${ }^{26)}$ The glassy alloy ribbon was also prepared by melt spinning. The glassy phase was identified by X-ray diffraction. The absence of microscale crystalline phase was examined by optical microscopy. The thermal stability associated with glass transition, supercooled liquid region and crystallization was examined by differential scanning calorimetry (DSC) at a heating rate of $0.67 \mathrm{~K} / \mathrm{s}$. The melting temperature $\left(T_{\mathrm{m}}\right)$ was measured by differential thermal analysis (DTA). Mechanical properties were measured with an Instron testing machine at a strain rate of $8.3 \times 10^{-4} \mathrm{~s}^{-1}$ for tensile test and $4.8 \times 10^{-4} \mathrm{~s}^{-1}$ for compressive test. Fracture surface was examined by scanning electron microscopy (SEM).

\section{Results and Discussion}

Figure 1 shows the shape and outer appearance of cast bulk glassy $\mathrm{Ni}_{53} \mathrm{Nb}_{20} \mathrm{Ti}_{10} \mathrm{Zr}_{8} \mathrm{Co}_{6} \mathrm{Cu}_{3}$ alloys in a rod shape of $3 \mathrm{~mm}$ in diameter and in a sheet shape of $1 \mathrm{~mm}$ in thickness. The outer surface is smooth and neither appreciable rugged- 


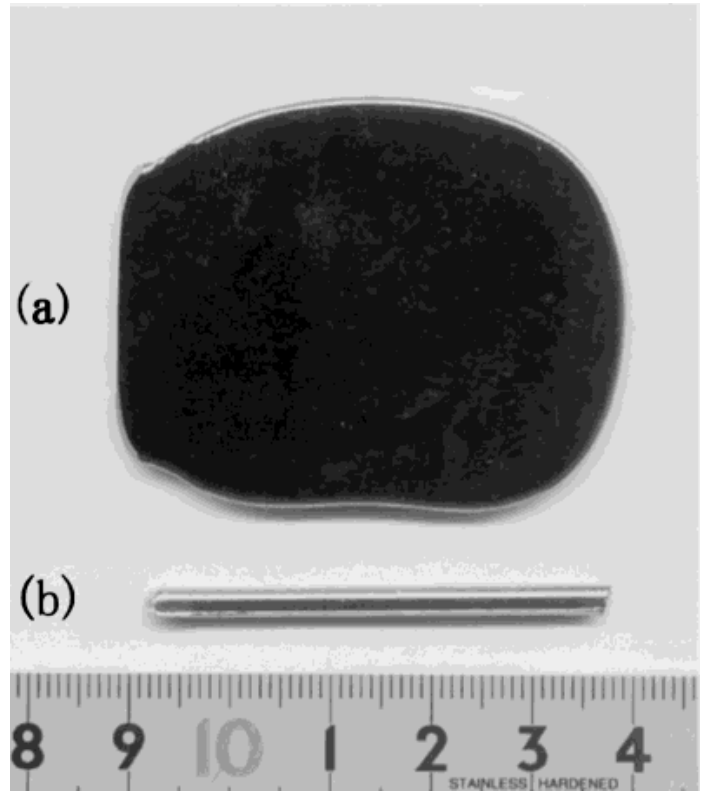

Fig. 1 Outer shape and surface morphology of cast $\mathrm{Ni}_{53} \mathrm{Nb}_{20} \mathrm{Ti}_{10} \mathrm{Zr}_{8} \mathrm{Co}_{6} \mathrm{Cu}_{3}$ alloys in rod and sheet shapes. (a) $\phi 3 \mathrm{~mm}$ rod and (b) $1 \mathrm{~mm}$ thickness sheet.

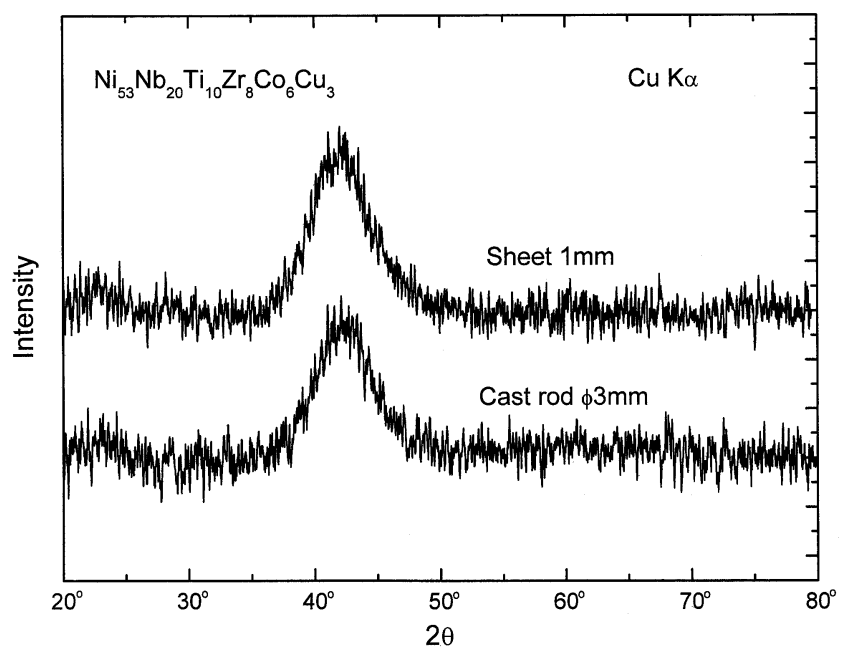

Fig. 2 X-ray diffraction patterns of the cast $\mathrm{Ni}_{53} \mathrm{Nb}_{20} \mathrm{Ti}_{10} \mathrm{Zr}_{8} \mathrm{Co}_{6} \mathrm{Cu}_{3}$ alloys in rod and sheet shapes.

ness nor concave is seen, indicating the formation of a glassy phase. The X-ray diffraction patterns of the bulk glassy alloys are shown in Fig. 2. The diffraction patterns consist only of broad peaks and no appreciable sharp diffraction peak due to a crystalline phase is seen. The feature of the X-ray diffraction patterns is independent of rod diameter. Figure 3 shows DSC curves of the bulk glassy alloys, together with the data of the corresponding melt-spun glassy alloy ribbon. All the samples exhibit a sequent phase transition of an endothermic reaction due to glass transition, followed by a large supercooled liquid region and then an exothermic reaction due to crystallization. The glass transition temperature $\left(T_{\mathrm{g}}\right)$ and onset temperature of crystallization $\left(T_{\mathrm{x}}\right)$ are 846 and $897 \mathrm{~K}$, respectively for the rod sample with a diameter of $3 \mathrm{~mm}$. No appreciable change in $T_{\mathrm{g}}$ and $T_{\mathrm{x}}$ was recognized in the present diameter range. In addition, one can see that the feature of the DSC curves as well as the $T_{\mathrm{g}}$ and $T_{\mathrm{x}}$ values is the same as those

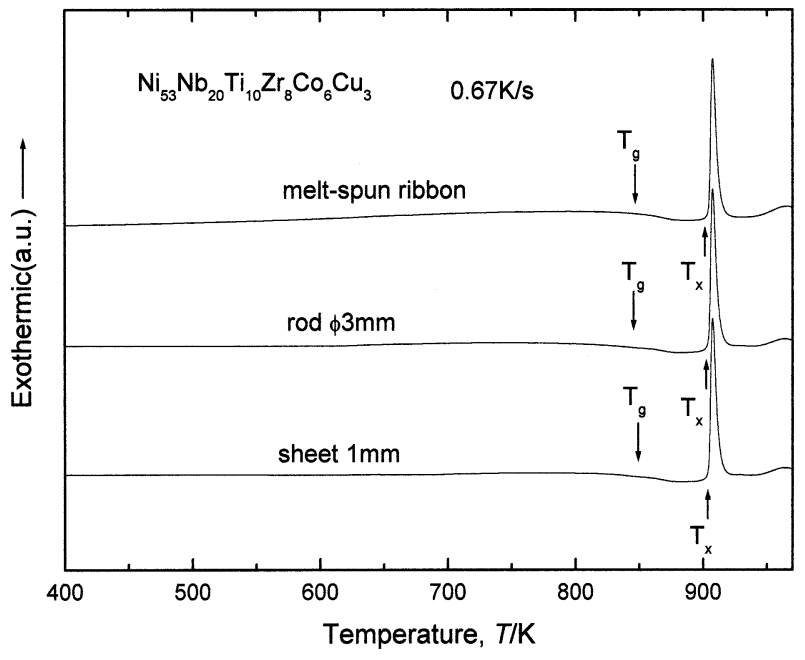

Fig. 3 DSC curves of the cast bulk glassy $\mathrm{Ni}_{53} \mathrm{Nb}_{20} \mathrm{Ti}_{10} \mathrm{Zr}_{8} \mathrm{Co}_{6} \mathrm{Cu}_{3}$ alloys in rod and sheet shapes.

for the melt-spun glassy alloy ribbon. Here, it is noticed that the bulk glassy $\mathrm{Ni}_{53} \mathrm{Nb}_{20} \mathrm{Ti}_{10} \mathrm{Zr}_{8} \mathrm{Co}_{6} \mathrm{Cu}_{3}$ alloys exhibit a large supercooled liquid region of $51 \mathrm{~K}$ which is defined by the difference between $T_{\mathrm{g}}$ and $T_{\mathrm{x}}, \Delta T_{\mathrm{x}}\left(=T_{\mathrm{x}}-T_{\mathrm{g}}\right)$. The $\Delta T_{\mathrm{x}}$ value is nearly the same as the largest value for a number of $\mathrm{Ni}$ based metal-metalloid type glassy alloys such as $\mathrm{Ni}-\mathrm{Cr}-\mathrm{Mo}-$ $\mathrm{P}-\mathrm{B},{ }^{27)} \mathrm{Ni}-\mathrm{Nb}-\mathrm{Cr}-\mathrm{Mo}-\mathrm{P}-\mathrm{B}^{27)}$ and $\mathrm{Ni}-\mathrm{Zr}-\mathrm{Ti}-\mathrm{Sn}-\mathrm{Si}^{28)}$ systems. Although the $\Delta T_{\mathrm{x}}$ value is considerably smaller than the largest values for the $\mathrm{Zr}-\mathrm{Al}-\mathrm{Ni}-\mathrm{Cu}^{29)}$ and $\mathrm{Pd}-\mathrm{Cu}-\mathrm{Ni}-\mathrm{P}^{8)}$ glassy alloys, the relatively large $\Delta T_{\mathrm{x}}$ value indicates that the supercooled liquid of the new metal-metal type Ni-based alloy has a rather high stability against crystallization.

We further examined the reduced glass transition temperature $\left(T_{\mathrm{g}} / T_{\mathrm{m}}\right)$ defined by the ratio of glass transition temperature $\left(T_{\mathrm{g}}\right)$ to melting temperature $\left(T_{\mathrm{m}}\right)$ by measuring the melting temperature with a differential thermal analyzer (DTA). As exemplified for the DTA curve in Fig. 4, the melting temperature is measured as $1265 \mathrm{~K}$. The $T_{\mathrm{g}} / T_{\mathrm{m}}$ value is determined to be 0.67 which is high enough to be judged as a high glass-forming alloy. In addition, it is seen that the melting of the $\mathrm{Ni}_{53} \mathrm{Nb}_{20} \mathrm{Ti}_{10} \mathrm{Zr}_{8} \mathrm{Co}_{6} \mathrm{Cu}_{3}$ alloy occurs through a single stage, indicating that the Ni-based alloy lies in the vicinity of eutectic point.

Figure 5 shows tensile and compressive stress-elongation curves at room temperature for the cast bulk glassy $\mathrm{Nb}_{53} \mathrm{Nb}_{20} \mathrm{Ti}_{10} \mathrm{Zr}_{8} \mathrm{Co}_{6} \mathrm{Cu}_{3}$ alloys. The tensile test was made for the sheet sample with a gauge dimension of $5 \mathrm{~mm}$ in width, $10 \mathrm{~mm}$ in length and $1 \mathrm{~mm}$ in thickness, while the compressive test used the rod sample with a gauge dimension of $2 \mathrm{~mm}$ in diameter and $4 \mathrm{~mm}$ in length. The Young's modulus $(E)$, tensile fracture strength $\left(\sigma_{\mathrm{t}, \mathrm{f}}\right)$ and tensile fracture elongation including elastic elongation $\left(\varepsilon_{\mathrm{t}, \mathrm{f}}\right)$ are $140 \mathrm{GPa}, 2700 \mathrm{MPa}$ and $2.1 \%$, respectively. Similarly, the compressive fracture strength $\left(\sigma_{\mathrm{c}, \mathrm{f}}\right)$ and compressive fracture elongation including elastic elongation $\left(\varepsilon_{\mathrm{c}, \mathrm{f}}\right)$ are $3010 \mathrm{MPa}$ and $2.4 \%$, respectively. The tensile fracture strength of $2700 \mathrm{MPa}$ is believed to be the highest for all bulk glassy alloys reported up to date. Figure 6 summarizes the mechanical properties in the relation between tensile fracture strength $\left(\sigma_{\mathrm{t}, \mathrm{f}}\right)$ and Young's modulus $(E)$, together with the previous data for other typical bulk glassy al- 


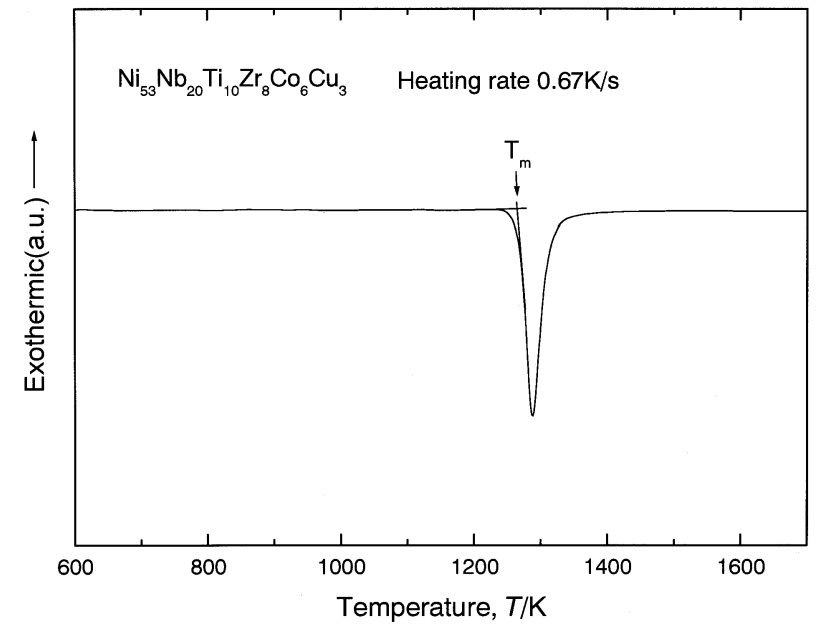

Fig. 4 DTA curve of the $\mathrm{Ni}_{53} \mathrm{Nb}_{20} \mathrm{Ti}_{10} \mathrm{Zr}_{8} \mathrm{Co}_{6} \mathrm{Cu}_{3}$ alloy.

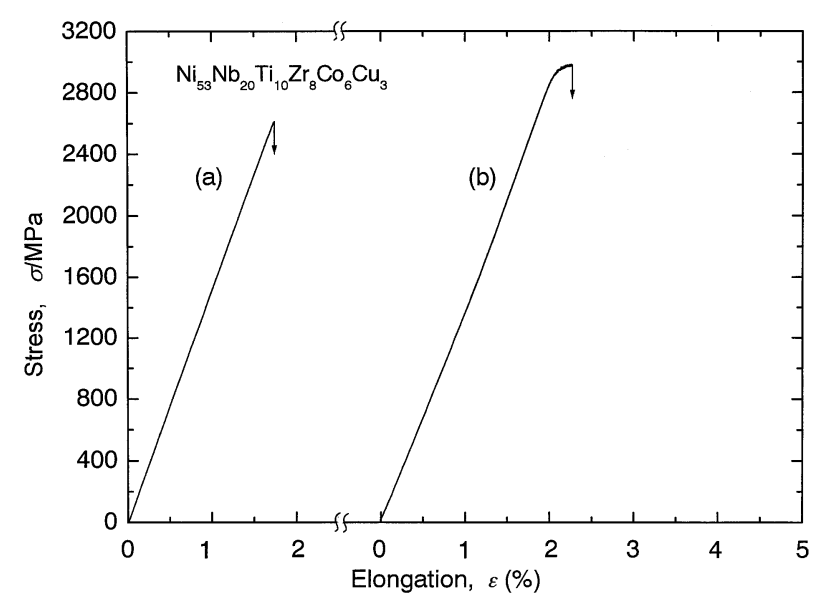

Fig. 5 Stress-elongation curves of the cast bulk glassy $\mathrm{Ni}_{53} \mathrm{Nb}_{20} \mathrm{Ti}_{10} \mathrm{Zr}_{8}$ $\mathrm{Co}_{6} \mathrm{Cu}_{3}$ alloys in rod and sheet shapes. (a) Tensile deformation of the sheet with a thickness of $1 \mathrm{~mm}$, and (b) compressive deformation of the rod with a diameter of $2 \mathrm{~mm}$.

loys and conventional crystalline alloys. ${ }^{24)}$ It is seen that the present data lie in the previous linear relation, indicating that the mechanism for the high strength of the present bulk glassy alloy may be the same as that for the other bulk glassy alloys.

With the aim of investigating the origin for the high strengthening mechanism for the present bulk glassy alloys, the tensile fracture strength was plotted as a function of $T_{\mathrm{g}}$ or $T_{\mathrm{m}}$ in Fig. 7. Although some scatterings are seen, one can see distinct linear relations between $\sigma_{\mathrm{t}, \mathrm{f}}$ and $T_{\mathrm{g}}$ or $T_{\mathrm{m}}$. Considering that $T_{\mathrm{g}}$ or $T_{\mathrm{m}}$ is dominated by the bonding forces among the constituent elements of the glassy alloys, ${ }^{30)}$ the high $\sigma_{\mathrm{t}, \mathrm{f}}$ value of the present $\mathrm{Ni}-\mathrm{Nb}-\mathrm{Ti}-\mathrm{Zr}-\mathrm{Co}-\mathrm{Cu}$ bulk glassy alloys is concluded to reflect the strong bonding forces among the main four elements of $\mathrm{Ni}, \mathrm{Nb}, \mathrm{Ti}$ and $\mathrm{Zr}$. This is consistent with the data that the negative heats of mixing for their main atomic pairs are $30 \mathrm{~kJ} / \mathrm{mol}$ for $\mathrm{Ni}-\mathrm{Nb}, 49 \mathrm{~kJ} / \mathrm{mol}$ for $\mathrm{Ni}-\mathrm{Zr}$ and $28 \mathrm{~kJ} / \mathrm{mol}$ for $\mathrm{Ni}-\mathrm{Ti}^{31)}$ On the contrary, the good ductility leading to appreciable plastic elongation seems to reflect the nearly zero heat of mixing for $\mathrm{Nb}-\mathrm{Zr}, \mathrm{Zr}-\mathrm{Ti}$ and $\mathrm{Nb}-\mathrm{Ti}$ atomic pairs. ${ }^{31)}$ In addition, one can recognize that the constituent elements have significant atomic size ratios of 1.18 for $\mathrm{Nb} / \mathrm{Ni}, 1.28$ for $\mathrm{Zr} / \mathrm{Ni}, 1.18$ for $\mathrm{Ti} / \mathrm{Ni}, 1.09$ for $\mathrm{Zr} / \mathrm{Nb}$ and 1.09 for $\mathrm{Zr} / \mathrm{Ti}^{32}{ }^{32}$ Based on these fundamental data on

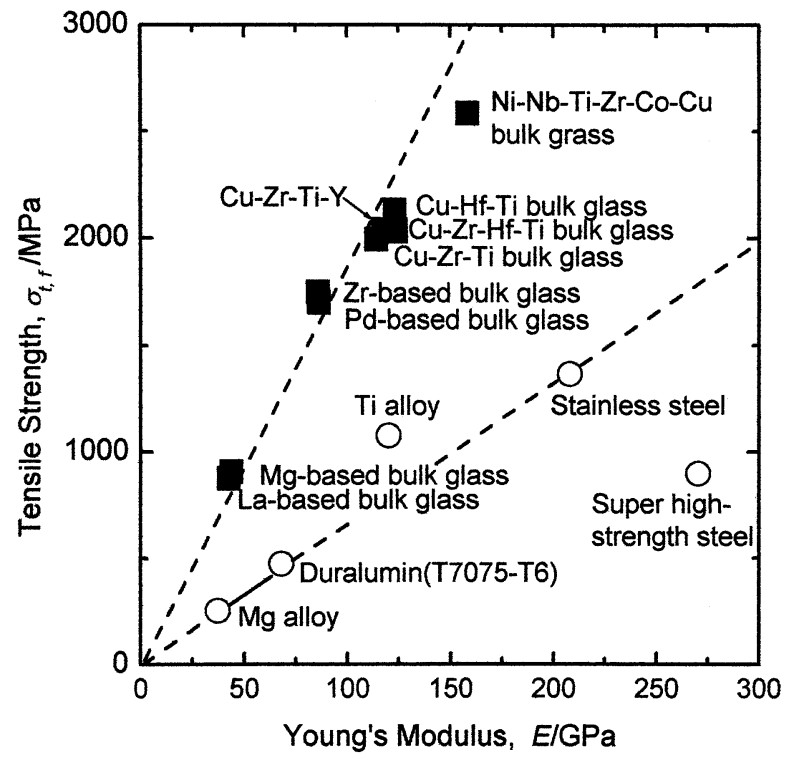

Fig. 6 Relation between tensile fracture strength $\left(\sigma_{\mathrm{t}, \mathrm{f}}\right)$ and Young's modulus $(E)$ for the cast bulk glassy $\mathrm{Ni}_{53} \mathrm{Nb}_{20} \mathrm{Ti}_{10} \mathrm{Zr}_{8} \mathrm{Co}_{6} \mathrm{Cu}_{3}$ alloy sheet. The data of the other bulk glassy alloys and conventional crystalline alloys are also shown for comparison.

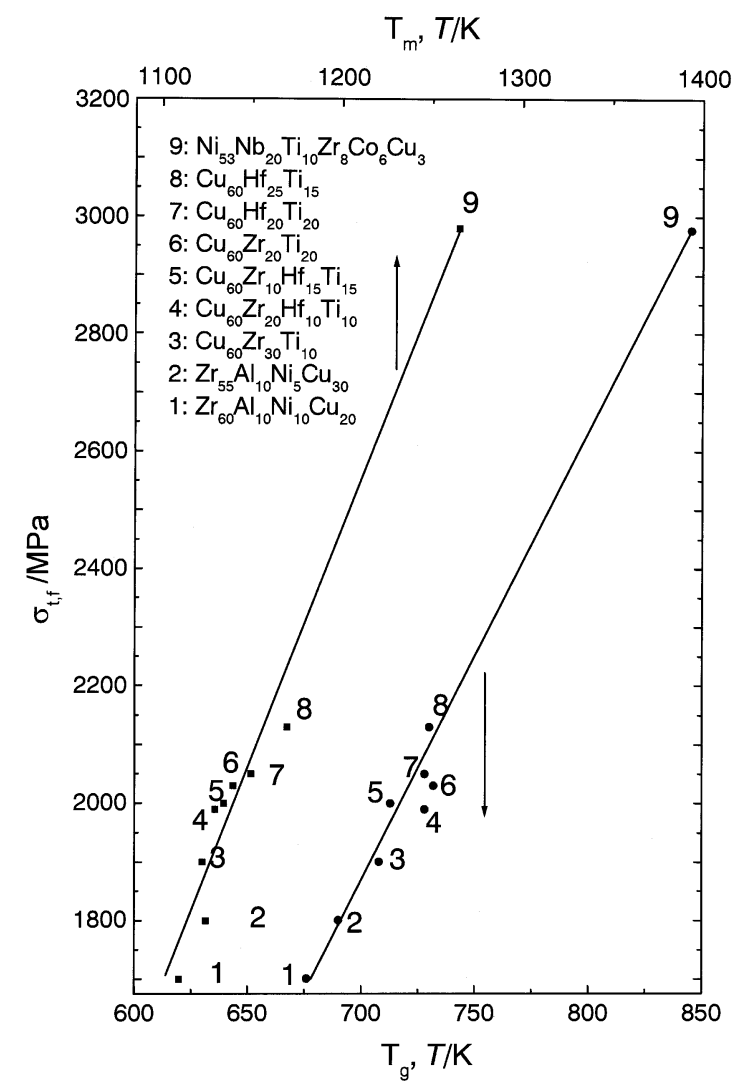

Fig. 7 Relation between tensile fracture strength $\left(\sigma_{\mathrm{t}, \mathrm{f}}\right)$ and glass transition temperature $\left(T_{\mathrm{g}}\right)$ or melting temperature $\left(T_{1}\right)$ for the cast bulk glassy $\mathrm{Ni}_{53} \mathrm{Nb}_{20} \mathrm{Ti}_{10} \mathrm{Zr}_{8} \mathrm{Co}_{6} \mathrm{Cu}_{3}$ alloy sheet. The data of the other bulk glassy alloys are also shown for comparison.

the bonding nature and atomic size ratios, the high strength combined with good ductility is due to the unique alloy components leading to the mixed state of the attractive and repulsive bonding natures for the constituent elements with significantly different atomic size ratios. Finally, it is important to point out that the present $\mathrm{Ni}-\mathrm{Nb}-\mathrm{Ti}-\mathrm{Zr}$ base alloy 
satisfies almost the following three criteria for achievement of high glass-forming ability, ${ }^{21-24)}$ i.e., (1) multi-component alloy system consisting of more than three elements, (2) significant atomic size ratios above about $12 \%$ among the main constituent elements, and (3) negative heats of mixing among their main elements. It is further said that the addition of the special elements with a nearly zero heat of mixing and significantly different atomic size is important for the achievement of high strength and good ductility for Ni-based metal-metal type alloys. The subsequent search for a new alloy in the framework of this concept is expected to prepare bulk Fe- and Co-based glassy alloys with high strength and good ductility.

\section{Conclusions}

With the aim of developing a new bulk glassy alloy with high tensile strength and good ductility in ferrous alloy group, we examined glass-forming ability and mechanical properties for Ni-based alloys where the three empirical criteria for formation of bulk glassy alloys are almost satisfied. The results obtained are summarized as follows.

(1) Bulk glassy alloys were formed in $\mathrm{Ni}-\mathrm{Nb}-\mathrm{Ti}-\mathrm{Zr}$ base system by the copper mold casting and mold-clamp casting methods. The maximum diameter was $3 \mathrm{~mm}$ for glassy $\mathrm{Ni}_{53} \mathrm{Nb}_{20} \mathrm{Ti}_{10} \mathrm{Zr}_{8} \mathrm{Co}_{6} \mathrm{Cu}_{3}$ alloy.

(2) The bulk glassy alloy exhibits the distinct glass transition, followed by a large supercooled liquid region and then crystallization. The glass transition temperature $\left(T_{\mathrm{g}}\right)$ and the supercooled liquid region defined by the difference between $T_{\mathrm{g}}$ and crystallization temperature $\left(T_{\mathrm{x}}\right), \Delta T_{\mathrm{x}}\left(=T_{\mathrm{x}}-T_{\mathrm{g}}\right)$ are 846 and $51 \mathrm{~K}$, respectively. In addition to the large $\Delta T_{\mathrm{x}}$ value, the bulk glassy alloy is located in the vicinity of eutectic composition and exhibits high reduced glass transition temperature $\left(T_{\mathrm{g}} / T_{\mathrm{m}}\right)$ of 0.67 .

(3) The Ni-based bulk glassy alloy exhibits Young's modulus of $140 \mathrm{GPa}$, tensile fracture strength of $2700 \mathrm{MPa}$, tensile fracture elongation of $2.1 \%$, compressive fracture strength of $3010 \mathrm{MPa}$ and compressive fracture elongation of $2.4 \%$. The high tensile fracture strength is roughly proportional to Young's modulus, glass transition temperature and melting temperature which reflect the bonding forces among the constituent elements.

(4) The finding of the new Ni-based glassy alloys with high glass-forming ability and good mechanical properties is encouraging for future development of bulk glassy alloys which can be used as high-strength structural materials.

\section{REFERENCES}

1) A. Inoue, T. Zhang and T. Masumoto: Mater. Trans., JIM 30 (1989) 965-972.

2) A. Inoue, K. Ohtera, K. Kita and T. Masumoto: Jpn. J. Appl. Phys. 27 (1988) L2248-L2251.

3) A. Inoue, T. Zhang and T. Masumoto: Mater. Trans., JIM 31 (1990) 177-183.

4) A. Peker and W. L. Johnson: Appl. Phys. Lett. 63 (1993) 2342-2344.

5) A. Inoue, K. Amiya, T. Zhang and T. Masumoto; Mater. Sci. Eng. A179/A180 (1994) 692-696.

6) T. Zhang, A. Inoue and T. Masumoto: Mater. Lett., 15 (1993) 379-382.

7) A. Inoue and J. S. Gook: Mater. Trans., JIM 36 (1995) 1180-1182.

8) A. Inoue, N. Nishiyama and T. Matsuda: Mater. Trans., JIM 37 (1996) 181-184.

9) T. D. Shen, Y. He and R. B. Schwarz: J. Mater. Res. 14 (1999) 21152117.

10) A. Inoue, M. Koshiba, T. Itoi and A. Makino: Appl. Phys. Lett. 73 (1998) 744-746.

11) A. Inoue, T. Zhang, N. Nishiyama, K. Ohba and T. Masumoto: Mater. Lett. 19 (1994) 131-135.

12) A. Inoue, W. Zhang, T. Zhang and K. Kurosaka: Acta Mater. 49 (200) 2645-2652.

13) A. Inoue, T. Nakamura, T. Sugita, T. Zhang and T. Masumoto: Mater. Trans., JIM 33 (1992) 937-945.

14) K. Amiya and A. Inoue: Mater. Trans., JIM 42 (2001) 543-545.

15) A. Inoue and T. Zhang: Mater. Trans., JIM 37 (1996) 185-187.

16) A. Inoue, T. Zhang and A. Takeuchi: Appl. Phys. Lett. 71 (1997) 464472 .

17) A. Inoue, N. Nishiyama and H. M. Kimura: Mater. Trans., JIM 38 (1997) 179.

18) T. Itoi and A. Inoue: Mater. Trans., JIM 41 (2000) 1256-1261.

19) X. M. Wang and A. Inoue: Mater. Trans., JIM 41 (2000) 539-542.

20) A. Inoue, W. Zhang, T. Zhang and K. Kurosaka: Mater. Trans., 42 (2001) 1149-1151.

21) A. Inoue: Mater. Trans., JIM 36 (1995) 866-875.

22) A. Inoue: Bulk Amorphous Alloys, (Trans Tech Publications, Zurich, 1998) pp. 1-116.

23) A. Inoue: Acta Mater. 48 (2000) 279-306.

24) A. Inoue: Mater. Sci. Eng. 304 (2001) 1-10.

25) Bulk Metallic Glasses, ed. by W. L. Johnson, C. T. Liu and A. Inoue (MRS, Warrendale, 2000).

26) H. Kakiuchi, A. Inoue, M. Onuki, Y. Takano and T. Yamaguchi: Mater. Trans. 42 (2001) 678-681.

27) A. Inoue, X. M. Wang and I. Yoshii: Mater. Trans., JIM 40 (1999) 1130.

28) S. Yi, T. G. Park and D. H. Kim: J. Mater. Res., 15 (2000) 2425.

29) T. Zhang, A. Inoue and T. Masumoto: Mater. Trans., JIM 32 (1991) 1005-1010.

30) H. S. Chen: Rep. Prog. Phys. 43 (1980) 353-432.

31) F. R. Boer, R. Boom, W. C. M. Mattens, A. R. Miedema and A. K. Niessen: Cohesion in Metals, (North-Holland, Amsterdam, 1988).

32) Metals Databook, ed. Japan Inst. Metals, Maruzen, Tokyo (1983) p. 8. 